\title{
From The Theory of Mimesis to Moral Corruption in The Family: A Literary Critique of Helon Habila's Measuring Time
}

\author{
Confidence Gbolo Sanka ${ }^{1}$, Abigail Mensah ${ }^{2}$ and Francis Elsbend Kofigah ${ }^{3}$ \\ ${ }^{1,3}$ Department of English- Kwame Nkrumah University of Science and Technology- Ghana \\ ${ }^{2}$ ACE Consult Ltd- $3^{\text {rd }}$ Floor- Top Martins Complex- Ghana \\ 1 fikoff75@gmail. com
}

\begin{abstract}
This paper investigates the motif of moral corruption that has taken root in the modern family. The focus is on Helon Habila's novel, Measuring time, and analysis is provided on Habila's use of language, characterisation, symbolism, collocation and the saturation technique to expose the motif of corruption that recurs in several aspects of human life and existence. It is the position of this paper that literature is a representation of life, and as a matter of fact, the key issues presented in the novel through different techniques reflect the reality and universality of moral corruption as seen in human behavior and experience. In this light, the meaning of corruption is applied to one key theme raised by the author: the concept of the broken family together with other related issues of corruption observed in the wars and politics of Nigeria and her sister African countries. Again, this paper investigates Habila's use of language as an intriguing medium to communicate his views on corruption as captured in Measuring time.
\end{abstract}

Keywords: Mimesis, Moral Corruption, Broken Family, Nigeria, Characterisation, Collocation, @ (ब) Saturation Technique.

\section{Introduction}

This paper investigates the causes and effects of moral corruption on the modern African family. Corruption generally can be divided into categories such as political, economic, moral and so on. No matter the kind of corruption involved, two things are clear: corruption is a "cultural phenomenon" and every type of corruption could have a "devastating effects" on the society and its population (Melgar, Rossi and Smith, 2010, p.1) The loss of "the very rule of morality, of our sense of good and evil" is what constitutes moral corruption (Besancon, 2007, p.36). The inability to discern between good and evil, and the inability to fight for the one and against the other is what leads to corruption in general. Many societies in Africa and across the world are unable to fight against corruption because they are limiting it to only the public life of the leaders while neglecting what goes on in the moral lives of the families that constitute the nation. Yet it is the family which produces the leaders. Habila's novel redirects our attention to this lacuna by concentrating on the rippling effects of moral corruption on the families that populate his novel, Measuring time. In this light, the meaning of corruption is applied to one key theme raised by the author: the concept of the broken family together with other related issues of corruption observed in the wars and politics of Nigeria and her sister African countries.

The theory used to advance argument in the paper is Aristotle's theory of mimesis which is also referred to as "imitation" (Aristotle, 1982, p.173). To Aristotle, imitation is not only "natural to men" but through imitation, men "are pleased when they see images because they have the experience of learning...”(1982, p.72-73). Both pleasure and knowledge are thus obtained through imitation.

The methodology used in gathering, presenting and analyzing data is qualitative in nature. Primary data is obtained from Habila's novel, Measuring time while secondary data is obtained from a review on the literature of mimesis and the literature on corruption in general. A literary and 
stylistic reading of the primary text is done by looking at the techniques of characterisation, symbolism, saturation technique, and collocation which are used to delineate the theme of moral corruption in the family in Helon Habila's narrative.

\section{Literature Review}

Literature is a representation of life (Agyekum, 2007, p. 2). It is therefore not surprising that many writers take the raw materials of their stories from the realities they either encounter or observe. Aristotle, in his Poetics, rightly observes this art of representation artists engage in and terms it imitation. To Aristotle, imitation occurs primarily because [it is an instinct that lies] deep within the human nature, "implanted in man from childhood". He further opines that men enjoy seeing their likeness because in observing the imitation, they find themselves "learning" and "inferring" so that even if one happens to have not seen the original, one may still derive pleasure in the apt execution of the imitation (Butcher, 2015, p. 5).

According to Aristotle, one of the means through which artists engage in imitation is by means of an object of imitation. Consequently, Aristotle chooses his object of mimesis as men in action who must either be of a higher or lower type, and such men, according to him, must be imitated or represented as better than in real life, worse or as they are (Butcher 2015, p.1).

Rene Girard presents another thought-provoking view on the theory of mimesis. Employing the concept of imitation, Gerard identifies and explains the function of violence in human culture. He refers to his perspective as the mimetic theory and stipulates that mimetic desire is the main foundation from which hostility and violence which typifies the human species spring. In other words, man's mimetic desire is the driving force behind the violence and negativity that rakes the world because therein breeds the conflicts of interests. In his book Violence and the Sacred, Gerard explicates this further by observing that:

Once his basic needs are satisfied (indeed, sometimes even before), man is subject to intense desires, though he may not know precisely for what. The reason is that he desires being, something he himself lacks and which some other person seems to possess. The subject thus looks to that other person to inform him of what he should desire in order to acquire that being. (1977, p.10)

From the above is an indication that goes a long way to support Aristotle's view on mimesis that it is intrinsically inherent in human nature and that there is always an object of desire which either consciously or unconsciously informs humans' mimetic needs. Gallese is of a similar view and attempts to explain Gerard's assertions as regards "appropriative mimicry" by observing that "it is the compulsory tendency of mankind to imitate other's desires, so that what is really desired and sought for is whatever is desired and sought for by others" ( 2009. p.2).

The art of imitation, however, goes beyond the mere representation or mimicry of negative desires, and both Gerard and Gallese acknowledge this. Gerard (1977, p.24) stresses that, "mimetic desire, even when bad, is intrinsically good, in the sense that far from being merely imitative in the small sense, it's the opening out of oneself" and it is also "the basis of love, viewed as the imitation of a positive model" (Gallese, 2009, p.3). Mimesis, representation or imitation can therefore be considered as a trait that is basic to mankind. It is employed as a tool or a means of propagating both positive and negative ideals in various human endeavours.

Following the idea of imitation or representation as postulated by Aristotle, modern writers imitate or represent the reality they experience in life in literature for several reasons and for several purposes. While some write with the aim of educating and entertaining, others write because they want to criticise the ills they find in society while upholding the commendable acts or behaviour they observe. In any of the preceding situations, the utilitarian aspect of literature or art cannot be denied. This is what Achebe means when he observes that, "Art is important but so is education of the kind I have in mind" (Achebe,1977, p. 45). 
It therefore comes as no surprise that Helon Habila, just like his cohorts, Chimamanda Ngozi Adichie and Sefi Atta imitates and represents myriads of social, cultural, political, economic issues they find within their society in their novels. In these novels, readers find the authors depicting the good, the bad and the ugly; the successes and failures representative of their various societies are depicted with the ultimate aim of correcting the ills they find in them.

Through his use of language and narrative technique, Habila discusses the theme of corruption as represented in the broken family, war and the petty politics observed within the Nigerian society. In this paper the definition of corruption is limited to the disappearance of family values such as love, parental support, care and warmth; the petty political bickering that results from the excessive human desire to wield political power at all cost and the ill effects of war on especially the people who experience it. In other words, corruption here refers to the loss of "the very rule of morality, of our sense of good and evil'(Besancon, 2007p. 36).

The theme of corruption that recurs in several aspects of human behaviour and experience is one that Habila dwells on extensively in his works. Corruption as a universal age-old demon is a motif that seems to have been entrenched in human life, and writers knowing the evils associated with it and its accompanying rippling effects have castigated the phenomenon from time immemorial till date.

The issue of corruption is almost always restricted to the negative practices that occur especially within political and government establishments such as the civil service, the legislature, executive and judicial arms of government. Consequently, a good number of writers all over the world pen their views on what they observe as corruption, especially within government institutions and establishments.

Writers like George Orwell, Elie Wiesel and Dante Aligheri in their writings Animal Farm, Night and Inferno all criticise what they view as corruption. Dian Fajrina in her work entitled "Character Metaphors in George Orwell's Animal Farm" concludes that Animal Farm which was first published in 1944 aimed at covertly disparaging "Stalin's way of governing by analogising it with the animal government" which had become a metaphor for the abusive communist government practiced by Stalin and his "Soviet Union leaders at the beginning of the $20^{\text {th }}$ century" $(80)$. The story of Night by Elie Wiesel, just like Animal Farm, also exposes the corruption associated with characters in positions of authority and reveals how the humane principles of love, kindness, benevolence, sympathy and empathy are gradually declining in human nature. Set within the confines of World War II, Wiesel, the author of Night reveals how many German doctors and scientists who were supposed to live up to their oath of providing care and health support to patients rather collaborated and massacred many Jews with the intention of helping Hitler achieve his demonic ideology of racial cleansing. In his work titled "Perspective Without Conscience" Wiesel himself admits that

\section{... during the period of the past century that I call Night, medicine was practiced in certain places not to heal but to harm, not to fight off death but to serve it... One day Hitler and Himmler's health minister made it known to leaders in the medical field that, ... executioners. $(2005,1551)$}

In fact, supposedly "powerful" Jewish prisoners were also perpetrators of similar inhumane acts on their fellows. In wanting to gain favour from the German SS guards, these "powerful" prisoners brutalized their compatriots to obtain better living conditions for themselves. Such prisoners referred to as "Kapos" willingly beat other inmates, and in return received things such as better food, clothes and better living conditions. Wachsmann elucidates on the role Kapos played in the furtherance of the Holocaust: 
Kapos generally served the interest of the Germans, principally the SS. Their priviledges did not exempt them from meeting SS expectations and failure to meet those could lead to punishment and dismissal. Serving SS interests translated into brutality on the part of most kapos... escorting condemned prisoners to execution sites, or killing them. (qtd in Akinrinade, 2017, p.10)

Not only European writers have captured the phenomenon of corruption in their works. In fact, African writers in a bid to make bare the stench of corruption in their various societies have written extensively about the subject. Writers like Chinua Achebe in A Man of the People and No Longer at Ease, Ayi Kwei Armah in his Beautyful Ones Are Not Yet Born and Osiris Rising comment on the state of post-colonial Nigeria, Ghana and Africa by painting a strong imagery of corruption and discussing the rippling effects of corruption on the conscience of the people who experience it. Macheka commenting on the issue of corruption and political disillusionment in Ayi Kwei Armah's Beautyful Ones Are Not Yet Born categorically states:

The Beautyful Ones Are Not Yet Born conveys a sense of resentment with the way in which corruption and bribery are universally accepted in Ghana as the only way to prosperity...Armah stresses his view by the use of symbols of sexual drawings on the toilet ...corpse. (2012, p.16-17)

The above reveals Ayi Kwei Armah's conscious and effective application of vulgarity through his association of corruption with the imagery of filth and rot to paint a mental picture of how corruption and sexual immorality has become endemic in his Ghanaian society. From the above, it becomes clear that indeed political disillusionment is a motif in Armah's novels, aimed at Ghana's and Africa's political corruption and failed advancement. It is again a reflection of the residual effects of imperialism on many post-independent African nations and the extension of a sequence of both social and economic marginalization. His gaudy depiction of the filth, rot and corruption of man's environs, where the community lavatory becomes the "cinema" for a people's depravities and the mark of civil and civic corruption indeed cannot go without mention.

More recent writers have viewed corruption from the negative effects people's actions bring to bear on the environment. Their views on decadence reflect the corrupt practices people engage in to dissipate and destroy the environment. In his publication entitled "Corruption and the Environment," Alexandra Leitao observes that "the earth's ecosystems are under increasing pressure from human activities, because of rising levels of greenhouse gases, habitat and species extinction, pollution, global climate change, and fish and water scarcity"(2016, p.1). He again identifies the unwillingness of institutions to deal with environmental issues and the lack of knowledge on the part of people as contributing factors to the menace of environmental corruption which he links with "...environmental degradation [that reflect and include] deficiencies in the basic needs of housing, clean water, sanitation, and health care" $(2016,1)$. The implication that could be drawn from the above is that the issue of corruption is not only related to lack of morality; it rather runs deeper to include the problems of the environment that contribute adversely to the lives of people. Corruption, then, is indeed a phenomenon that has negative consequences on the moral, social, political, cultural and economic well-being of a people and therefore must be combatted in order to minimise it.

Writers have succeeded in portraying and continue to portray the corruption and decadence within government establishments and the environment, and it appears that their attention is lost on the corruption that is steeped in the age-old institution of the family. The institution has been the bedrock upon which societies are built but its unity and ability to nurture are now under new challenges. In her article entitled "Declining Family Affinity and Decadence in Society", Helen Ovbiagele bemoans the state of the modern family as follows: 
Once upon a time, not so long ago, family was everything to us. Parents, siblings, family members, all came first in our lives. You couldn't do without them. They were the first you turned to in adversity and in sharing of good news. The family had so much influence on the individual that you thought ...Sadly, that affinity seems to be disappearing fast as [sic] among young people of this generation... the thought that [most people] could prefer...friends to ...relatives didn't make sense to me... I began to realize this could be the trend now...(htpps://www.vanguardngr.com/2013/03/declining-family;affinitydecadence-in-the-society/)

The sorry state of affairs of the institution of the modern family and its inability to provide the necessary warmth, comfort, love, sense of belongingness, discipline and so on such that people are beginning to lose faith in it is worrisome. It appears people are losing sight of the fact that values either positive or negative cultivated at home are the same perpetrated in the open society. As Helen Ovbiagele rightly observes: "A parent who thinks it's alright to steal public funds, asks for bribes, cheats in business, spends money entrusted to his/ her care is unlikely ...honest citizens." (htpps://www.vanguardngr.com/2013/03/declining-family;affinity-decadence-in-the-society/) Again, she opines that "those parents, who feel that having good moral values are meant for characters in fiction books on religion and not for real life, are ...wrong." (htpps://www.vanguardngr.com/2013/03/declining-family;affinity-decadence-in-the-society/) She is of the view that that "children brought up by parents who are uncouth, disruptive, and who settle...citizens." (htpps://www.vanguardngr.com/2013/03/declining-family;affinity-decadence-inthe-society/)

It follows then that society as a whole has a problem now that almost all positive values cultivated from this bedrock which are needed for the survival of the society are being shunned. A frightening fact is that the youth who are the future leaders are already engaged in irresponsible acts, and what is worse, many of the adults of this generation are negative role models. Consequently, morality like caution has been thrown to the wind such that "the texture of social life of contemporary world and [for that matter the family] is permeated with evil and threats, family disorientation, divorce, adultery, marital infidelity, child abuse..." (Iherue, 2011, 25).

The importance of the family to individuals, societies, nations and states, then, cannot be overemphasized if there is the slightest chance of redemption. It is a popular axiom that charity begins at home. It is therefore laudable and heartwarming that novelists and writers in general have and are still making significant strides to engage the minds of readers on the corruption that contributes to the breakdown of the family and the other attendant effects it visits on the society in terms of wars and the petty political foolery evident in many societies, especially in Africa. To examine corruption is to reveal the nature and the enigma of human behaviour in order to expose the hypocritical tendencies within man that draw him constantly to the evils of corruption (moral, political, economic, social and the likes). Man openly despises these ills but secretly adorns and even relishes. The tendency to corrupt and be corrupted is in man, and it takes a critical and candid approach to uncover the veil that hides it from sight.

\section{Synopsis Of The Novel}

Measuring time, to a large extent, examines the corruption or decline of family values of parental love, support, warmth and care as the root cause of the myriad social challenges in modern times. It is the story of twin brothers Mamo and Lamamo who hail from Keti. They reside with their father Lamang and their paternal aunt, Marina in the absence of their late mother Tabita. Mamo and Lamamo are resentful against their father Lamang because he shows no love and interest in their lives, and because they come to believe the village rumours that their father Lamang is the cause of their mother's death, they decide to punish him by running away to join the military without his 
knowledge or blessing. Lamamo succeeds, while at back at home, Mamo fights to deride his sickle cell disease and tries hard to make his life useful. Meanwhile his father, Lamang, pursues his political ambitions which terribly back fires. As Mamo grows, his life as a history teacher and as the biographer of his village's history exposes to him the reality of the failed leadership of his family and village.

\section{Analysis}

Measuring time is proliferated with the thematic concern of corruption of moral ideals demonstrated in the loveless relationships and the generational conflicts that exist between parents and their children. Because the family acts as a microcosm of the bigger picture involving the society, the corrupted moral ideals adopted from the home, by extension, have an adverse effect on the society at large as exemplified in the petty political gimmicks and squabbles observed in the modern African home and community respectively. Through the author's use of symbolism, language, extensive or detailed characterization and the saturation technique, Habila succeeds in portraying, the condition accountable for "the breakdown of the family or the disappearance of family values of [fidelity], parental love, care, warmth and support [as the] root of the myriad social pathologies afflicting contemporary societies" (Anyokwu, 2008, p. 7).

Anyokwu (2008, p.7) postulates that "Helon Habila uses the Lamang family as a paradigm or template to mirror the unsavory state of affairs of the family as a social unit in the contemporary world." Right from the beginning of the story, readers encounter the character Lamang who is described as the king of women__ a name he acquires as a result of his excessive philandering before and after his marriage to Tabita, the mother of his twins.(Habila, 2007, location103) Through gossip and the popular village songs hummed by women of the sexual escapades of Lamang from his village Keti to the state capital, his twin sons learn of how he breaks their mother's heart because he marries her not for love but because he sees Tabita, their mother, as a means of accruing the wealth of Tabita's old father for himself: "...Lamang, a shrewd business man, even then, had immediately seen the financial benefits of such marriage"(Habila, 2007, location 122). After all, he had been refused a chance to marry the love of his life Saraya because of his "penniless charms" (Habila, 2007, location 111). Tabita, consequently becomes the scape goat who bears the full brunt of the rejection and pain Lamang suffers from his denial. In fact, the pain Tabita experiences throughout the fifteen months she marries Lamang is personified in her final thoughts at the point just before she gives up the ghost. She does not know that despite her sickly disposition, she successfully brings two young lives into the world:

Tabita screamed and thrashed about and in lucid moment just before she died, she contemplated how life had given her all she had wanted with one hand and then taken it away with the other: she had married the man of her dreams, but he was in ... (Habila, 2007,location 142)

In Tabita's pain, she personifies life, an abstract idea as a being capable of giving willingly and snatching forcefully what it gives. She bemoans her suffering as a result of the loveless marriage she enters into with Lamang and dies a forlorn woman knowing that she, as a married woman, never experienced what true love is. Surprisingly, Tabita is not the only one who suffers Lamang's loveless dispositions; her two sons too experience same. Right from the very moment they are born, their father, Lamang, rejects them when their aunty Marina approaches him with the twins: "...she lifted the bloody bundle and approached her brother with it, but he lifted his hand, stopping her..." (Habila, 2007, location 150). Because of Lamang's rejection, the twins when taken by Aunty Marina to live with Uncle Iliya and his wife Amina, are referred to as "orphans" as if they had lost both their parents: "Take them, poor orphans, they are now yours..." says Aunty Marina. (Habila, 2007, location153) Consequently, the severance of ties between Tabita and her children and by extension 
Lamang and his sons weigh a toll on the boys causing them to hate their father. As Anyoku rightly puts it:

The severance of ties between mother and children (and by extension between father and sons) symbolizes a form of alienation from nature as maternal essence, nurturing, protective, therapeutic and remedial. The impression of the world gained by the twin brothers is that of existential xenophobia, cosmic ennui, despair, and meaningless misery ... (2008, p.7)

Lamang, therefore, serves as a symbol of failed authority whose moral corruption is exemplified in his loveless relationship with his wife and children as well as his infidelity and these contribute to the emotional abuse the twins go through in life. The consequence is that both the wife and children also view society as bereft of love and incapable of nurturing.

Zara's young family is another one Habila uses further to symbolize the concept of broken home and its attendant moral corruption. As a young woman, Zara marries the love of her life. However, the joy and happiness that characterises her family's life is short lived since her husband, George, a shallow young military man, after the birth of their son Sam begins to seek comfort and joy outside his matrimonial home with his friends in the arms of other women. The neglect and loneliness Zara feels causes her to experience extreme psychological trauma that almost pushes her to murder her own son. When she goes to seek advice from her mother, the mother desserts her by asking her to cope with the husband who beats and molests her mercilessly. To Zara's mother, Zara's husband is the man and it is expected of soldiers to behave the way does. Zara refuses the advice of her mother and divorces her husband but quickly falls in love again with Mamo. After several sexual escapades with him, Zara deserts Mamo and flies to South Africa with her university heartthrob, Thembe, on a mission to commence a charity foundation. They both enter a contractual marriage of convenience, but when Thembe begins to desire real commitment from Zara, she deserts him yet again and quickly flies back to Nigeria to start work in a clinic as an auxiliary nurse.

Considering the life of Zara, one can conclude that Zara becomes a representation and an embodiment of loss due to the loveless and abusive experiences she goes through in the hands of her husband and her mother. George is an embodiment of patriarchy gone wild: a symbolic representation of a tyrannical, self-serving authorities who derive their own importance by spiting, thrashing and emotionally and psychologically abusing others they deem weaker or subservient to them. Zara, rendering an account of her experience with her husband George recalls that:

I remember the first time he slapped me. I had caught him red-handed with a girl in his car as I passed them on the street. When I asked him about it later at home he just raised his hand and slapped me... The next one was this one with a belt. He ...I drove to my mother, and only when I got there did I realize how much I was bleeding...( Habila,2007, location 1608)

Zara's mother is an ironical foil of the progress achieved so far in the fight for equality pursued by women all over the world. Her character trait is in consonance with the village widows of Keti who willingly throw themselves at Lamang hoping to catch his attention; they are detractors to the struggle for progress or change. Zara's mother's silent endorsement of George's brutality is beyond comprehension; and it is against all efforts made by theorists and practitioners of feminist ideological principles to bridge the gap of inequality and fairness between women and men. The widows' overly dependence on Lamang reveals the truth about how the concept of patriarchy is deeply rooted not only in some men but also certain women who are so programmed by patriarchy that they believe, even in this modern day, that their self-worth depends on their ability to secure a man in marriage or otherwise who will bear the cusps of all their needs and wants? It is not surprising therefore that such women, like the widows, are true agents of patriarchy. They sit idly without making any attempts at positive and acceptable initiatives that are likely to set them on the path of attaining emotional, psychological and financial independence. Patriarchy, like leprosy, has 
crippled such minds and blinded their eyes so that they have become incapable of imagining any kind of existence without relying or depending on men.

Again, it seems against all odds for a woman and a mother for that matter to force her daughter back into a loveless and terrible marriage simply because of material gains. When Zara first approaches her mother in order to confide in her about her marital woes, the mother tells her "that [is] how military men behaved, that [she] had to be patient; that he'd soon come home, and that after all he had bought [her] things, jewelry, and recently a car..." (Habila, 2007,location 1597) The Marxist principles of commodification and consumerism are both implied here since according to Zara's mother, Zara's worth depends on her exchange value for material wealth and how often such material items are showered on Zara's mother.

When the situation gets worse such that Zara barely escapes with her life and that of her child, her mother reprimands her and sends her back to her husband's house. Zara refuses; her mother becomes angry and accuses her of wanting to bring shame to their family... that she is too strong minded not like her sister. (Habila, 2007,location 1597) It is the same emotional appeal that Uju's mother resorts to in "Possessing the Secret of Joy" in order to blackmail Uju and force her to go into a loveless marriage. Both Zara's and Uju's mothers are not mere agents of patriarchy or women committing violence on other women, but they contribute significantly to the rippling apart of the family by denying their daughters a mother's love and by pushing them in marriages bereft of love and the nurturing capabilities that are intrinsic in the institution of the family.

Zara's situation worsens when her mother willingly gives Zara's child away to George, her husband, without thinking of the trauma Zara would go through. This situation sets the ball rolling for Zara's insatiable thirst for belongingness, happiness, peace and inner joy which all elude her and consequently drive her into other different promiscuous, loveless affairs and later on to the depression she suffers finally.

Regardless of the differing opinions on the myriad feminist ideological stance (whether radical feminism, stiwanism, motherism and so on (Walker, A. 1983, Ogundipe, L. 1994, Acholonu, C. O. 1995), none endorses treating women as beasts. It is therefore worrisome to know that brutality of women still seems to be acceptable even among some women. For such people, education seems to be the only key capable of rescuing them from their ignorance. To Anyokwu:

\section{Zara represents in Measuring Time unrealized and botched potential: a gifted and intelligent beautiful woman, starry-eyed and ambitious, and potentially revolutionary [against the weight of patriarchy condoned by some women], she is separated from her child and cannot settle down with a man of her dreams, and shorn of family support, Zara ends up an embodiment of loss. (2008, p. 10)}

Turning to the family of Uncle Iliya, there is evidence in the novel to indicate that the man is a complete symbol of hope. Iliya is the elder brother of Lamang. He is first mentioned to readers when the twin brother's Mamo and Lamamo are sent to him and his wife after their mother dies through child birth. For the three years Mamo and Lamamo lived with him and his family, they grow up believing him and his wife, Aunty Amina, to be their real parents only for Lamang to shatter their illusion one day.

Uncle Iliya is a purposeful man, a firm disciplinarian who will not compromise on his moral principles just to please anyone. He is to Mamo the father he never had in Lamang, but to his own son, Asabar, Uncle Iliya is the albatross threatening to ironically "destroy" his "peace", and his desire to satisfy his self-indulgent cravings eventually leads to his doom. Asabar is the symbol of rebellion characteristic of modern youth who blatantly show disregard and dishonor for authority symbolised in Uncle Iliya. As regards him and Lamamo, they are the epitomes of the uncurtailed fantasies of adventure in the modern youth who are zealous, willing and eager to experiment everything without enough knowledge and wisdom. Asabar and Lamamo are foils to Mamo whose traits prove that zeal with character, knowledge and wisdom produce positive results. 
As a strong, purposeful altruistic man, Uncle Iliya forecasts the future of his village and foresees a foreboding menace if nothing is done to salvage the future of the youth. He selflessly dedicates his life to educate the future generation to equip them with the necessary skills needed for survival by establishing a vocational school. The school serves as the community's training center even though Lamang's political ambition, to some extent, jeopardizes the administration of the school because his political opponents use it as a tool to stifle Lamang's political ambitions.

Uncle Iliya, like Zara, is a symbol of change, hope, revolution a revolution that is not nipped in the bud like Zara's but one that actually materializes as inspiration for others. He is the wide eyed sentinel who would watch and guard society against influences either from within or without _that are most likely to have negative consequences, and will question norms and practices he views as abhorrent and inexplicable in the context of his society. He tells his Nephew Mamo never to accept issues "at face value" and not to "agree with what a man says because he has lived longer... or because he claims that is our way using history as evidence..." (Habila, 2007, location1227) In his stoicism and pragmatism, Iliya has the strength to acknowledge and accept that fallibility is accustomed to every aspect of human existence. Therefore the older generation cannot be allowed to perpetrate customs and practices which are obsolete without explaining their relevance to modernity. Uncle Iliya advocates understanding and pragmatism as opposed to gullibility. $\mathrm{He}$ opines that "If [one] wants to follow tradition, [one] must follow it because [one] understands it, not because some old man told [one] it is our way..." (Habila, 2007, location 1249). His views on religion are as revolutionary as they are on culture and tradition, and he cautions those who indulge in fanaticism because to him "[it] is never the answer [but] gives rise to fascism and all sorts of racial and religious fundamentalism." (Habila: 2007, location 1249)

Lamang, Uncle Iliya, Mamo, Zara, George, Lamamo and Asabar are symbols that reveal the dichotomy of modern society where there is a constant defiant struggle between the forces of good and evil, rationality and irrationality as in Christopher's Marlowe's Doctor Faustus (1984, p.31). Through these characters, Habila succeeds in portraying to readers the moral corruption that has gripped the modern family as exemplified in the coarse relationship between fathers and sons, mothers and daughters; and husbands and wives and the rippling effects they have on the society at large.

In Key Terms in Stylistics, Nina et al define the study of stylistics as "the study of the ways in which meaning is created through language in literature as well as other types of text" (2010, p. 1). In order to beautifully and accurately communicate his message to his readers, Helon Habila consciously employs the elements of style and figurative language to reveal the oddities and corruption he observes within his society and particularly within the institution of family.

In the publication entitled "Deviant Collocations as a Writing Technique in African Literature: A Stylistic Study of Helon Habila's Measuring Time", Onyekachi Jacinta Awa observes that Habila makes extensive use of deviant collocation in his work. In explaining collocation, she refers to Sinclair (1991) who defines the term as "items that occur physically together or have stronger chances of being mentioned together." According to Hill and Lewis (2000, p.13), collocation handles word combinations that are predictable. For instance, it is highly predictive that the word "handsome" will naturally collocate with either a man or a boy as in the expression "a handsome boy" or a "handsome man, and the word "blond" will also collocate with "hair" as in the expression "blond hair."

Habila deliberately bends the naturally accepted rules of collocation arbitrarily to portray the confusion and complexity his characters find themselves in. These deviant collocations are typified in the personifications, metaphors, paradox and oxymoron he employs in presenting the incongruity and decadence he finds within his society. For instance, as stated earlier in the novel, readers are informed that Tabita's involvement in a loveless marriage with Lamang causes her too much pain, such that at the time she is delivered of her babies, she personifies life, an abstract idea as a being capable of giving willingly and snatching forcefully what it gives. By personifying an abstract idea 
as a being capable of giving willingly and snatching forcefully what it gives, she bemoans her suffering as a result of the loveless marriage she engages in with Lamang. Readers are made to experience Tabita's situation of loneliness, seclusion and isolation she feels even in a marriage which is in sharp contrast to the feelings of love, warmth and companionship one is to feel in marriage and within a family. Again, Lamang's rejection of her newly born sons after their birth and immediately after the death of their mother makes his sister Marina refers to them as "...the mewling content of the blanket..." This incongruous fusion of descriptive words given the twins in referring to them as "...mewling content of the blanket..." (Habila, 2007, location 153) reveals a deviant collocation of words which merge or transfer animalistic description to humans in order to paint a grotesque mental imagery of loneliness and vulnerability. As Onyekachi Jacinta Awa (2016, p. 30) observes it in her paper, "Helon Habila uses [such] metaphorical distortions to depict the beastly behavior of some humans, especially the ruler towards their fellow humans (the ruled)" which, in this case, signifies Lamang's inhuman treatment of his children and his wife even to the point of his refusal to attend the final funeral rites of his wife, Tabita. Another example of a character who suffers loneliness amidst friends and relatives is Aunt Marina. To vividly portray her loneliness, Habila gives readers a sense of her loneliness in the description below:

The stories she told us and the neighbourhood children in front of the mud kitchen, far into the moonlit night, she told not only to entertain us, but also to push back the time when she'd have to go to her lonely bed and stare at the bare wall that mocked her nightly with images of her failed life (Habila, 2007,location 208)

In the above quotation, the word "story" is made to have the ability of "pushing back", and the word "wall" is given the human quality of mocking. Knowing that Aunt Marina comes to live with her brother, Lamang, because of her failed marriage as a result of her inability to produce children for her husband, readers are made to experience at firsthand, the dejection Marina feels. She is surrounded by Mamo and Lamamo; and their father Lamang, yet Marina still desires the company of the people who truly define her existence and her relevance in her community: her husband and her unborn children. Mamo and Lamamo are no exception to the feelings of loneliness and dejection. In fact, from the time they are brought into the world, they meet loneliness starring them right in the face. Their mother dies through childbirth; their father shows no interests in their young lives. They have to live with foster parents, and this leaves a constant longing and yearning for the love and presence of their biological parents. Indeed, the first time they are introduced to uncle Iliya, they are referred to as "...the mewling contents of the blanket" exposing their weakness and vulnerability even when surrounded by family. Again, the constant longings and yearnings that are never satisfied make Mamo, the elder twin try against all odds to obtain some mental and psychological connection to the motherly love he desires from his dead mother. In the biography he later pens about Keti, he writes about his own mother and tries to depict the happenings of the moment before she gave up the ghost which happens to be the very night he himself is born:

Tabita lay in a narrow bed, sweaty, fainting, her hands grasped tightly by the midwife who was sitting on the edge of the bed. A single lantern, fighting valiantly against the wind that leaned with both hands on the wooden door and the darkness that advanced and withdrew playfully in umbra and penumbra...

(Habila, 2007, location 140)

It is observed from the above that Mamo, through his diction, paints a horrifying gloomy picture that creates a mental imagery of the confusion and despair that shrouds his birth and the death of his mother. It also becomes the fuel that burns his hatred for his father in that the personified descriptions reveal the background to the pain their mother goes through as a result of their father's neglect. From this, readers are given a sensual, unpleasant feel of the mystery that surrounds life and death as binary opposites and an irony: there is death in life and life in death. The imagery evokes a 
sense of sadness and pity in readers for Mamo and Lamamo because a vacuum that can never be filled leaves a hollow within it.

Tabita's sadness in the lifetime of her brief marriage coupled with Mamo's constant fight to deride the sickle cell disease is depicted in the following quotes: "The glow on their mother's cheek hid the incipient dark tinge of sadness and apprehension" (Habila, 2007,location 214) and "she taught me to live with it, how to deride it even" (Habila, 2007,location 191) respectively reveal the paradox that surrounds Tabita and Mamo's life and by extension the lives of all characters in Measuring time.

To as well reveal the dilemma representative of his country, Habila adopts a writing technique that allows him to set his story in history which, to a very large extent, exposes and reflects Nigeria's "checkered history of military dictatorships, economic stagnation, social misery and political misrule... from the mist of antiquity through pre-colonial, colonial to post- colonial era" (Awa, 2016, p.20). The novel explores the missionary history of Nigeria as a precursor to colonialism and uncovers the root causes of the religious violence in Jos Plateau region. According to the historical depictions in the novel, the first Mai of Keti is a Christian but the subsequent Mai's inability to uphold the Christian tenets of monogamy and his subsequent decision to convert to Islam sparks religious violence and turbulence in the region (Akung, 2012, p. 147).

In addition, Measuring time (just like his other novels Waiting for an Angel and Oil on Water) reveals the failure of the political institutions and the military in alleviating poverty and minimising corruption, looting, inflation, high cost of living, poor management of resources, blatant disregard for human rights, and electoral fraud(Akung, 2012, p.147).

The history of the Biafran war is not left out in Habila's historical novel as it reflects the effects of the war on the lives of people, particularly soldiers, represented in the lives of Uncle Haruna, Uncle, Iliya George and Lamamo. Uncle Iliya in describing the absurdity of war says:

\section{My war ended in 1968. I was shot in the arm... I spent the remaining months of the war in a military hospital in Kaduna. It was a terrible time. I saw more death and more suffering than I had seen in the second world war... (Habila, 2007, location 542)}

Uncle Haruna, on the other hand, is unlucky because the war destroys the human essence in him: "But by now, it [was] clear that there [was] something wrong with uncle Haruna _ he didn't seem to be able to remember much" ( Habila, 2007, location 548). Haruna's loss of self as a result of his long stay at the war front is in consonance with Lomba's loss of self as a result of his long confinement in jail without trial in Waiting for an Angel. Lamamo's experience also depicts that of mercenary soldiers who get involved in wars fought in other neighbouring states. Through Lamamo's letters, Habila adopts an epistolary approach as he is able to narrate from the characters perspective firsthand experience of the brutalities of war without authorial interruption. George is a representation of the class of military men who are irrational, visionless and lack ideological values. Lastly, Habila exposes the issue of electoral fraud in Nigeria and by extension Africa as a whole. The problem of electoral fraud otherwise known as vote rigging as an illegal interference with the process of an election has increasingly gained notoriety in many parts of the world. Even in countries well known for best practices when it comes to democracy such as the United States, the phenomenon is still a threat. One typical example occurred in the United States in relation to what has become known as the "Bleeding Kansas" election of March 30, 1855. Held to decide whether Kansas was to be a free state or a slave state, the election saw massive rigging and subsequent riots which claimed the lives of both pro-slavery and abolitionist members (Napier, 2011, 29-30).

Africa's experience in electoral fraud is no exception, and that is what Habila aims at portraying in order to engage his readers. He depicts this phenomenon by presenting Lamang and Asabar as symbols of political sycophancy in order to condemn the act. When Mamo chances upon Asabar and his political thugs who work for Lamang, he finds them thumb-printing ballot papers they have forcefully taken. He questions them, and the following ensues: 
"What are you doing?"

"We are voting already", Asabar said with a laugh. The three echoed his laughter as they dipped their thumps into a blotter of ink before pressing them on the white square space next to the rooster logo on the ballot...

"So what are you going to do with the cards?"

"You don't want to know" Asabar said but then he went on almost eagerly "we will take them to the polling station and put them in

the ballot boxes. That is how you win elections" (2007, Location 2646)

By raising this issue, Habila appears to be implying that this canker must be smoked out in order for the peace that people, societies and nations enjoy be maintained.

\section{Conclusion}

This paper has examined corruption as a motif in the gradual destruction of the institution of family together with its rippling effects of war and petty political bickering on the society and the nation. The concept of corruption has been applied to the key issue raised by Habila in his novel. The broken family is the source of moral corruption which leads to war and politics; and the negative effects they have on the physical and psychological makeup of the people in the fictional world of Habila's novel. Through characters such as Mamo, Lamamo, Lamang, Uncle Iliya and through narrative techniques such as saturation, symbolism, unusual collocations and the epistolatory style, Habila succeeds in imitating and representing real life issues in his novel with the aim of drawing the readers' attention to the crises the family as an institution is faced with. The rippling effects of such crises on the society, the nation and the world at large are also fictionalised in Habila's novel.

\section{References:}

[1] Achebe. C., The novelist as teacher, Morning yet on creation day, London: Heinemann, (1977)

[2] Agyekum. K., Introduction to literature, Accra: Media DESIGN, (2007)

[3] Acholonu. C.O, Motherism: The Afrocentric alternative to feminism, Owerri, Nigeria: Afa, (1995)

[4] Akinrinade. B., Judging the impossible: Kapos and justice after Holocaust Reflections Auschwitz Jewish Center Annual Alumni Journal, (2017), 9-17

[5] Akung. J.E, New historicist dimensions in Helon Habila's Measuring time, International Journal of Applied Linguistics and English Literature,1(4)(2012), 144-151, https://doi.org/10.7575/ijalel.v.1n.4p.144

[6] Anyokwu. C., Inheritance of loss: Narrative and history in Helon Habilah's Measuring time, Carlifornia Linguistic Notes, 33(2)(2008), 1-27.

[7] Aristotle, The poetics, Literary criticism: From Plato to Dryden, edited by Allan H. Gilbert, $6^{\text {th }}$ Edition, Michigan: Wayne State University Press, (1982)

[8] Awa. J.O, Deviant collocation as a writing technique in African literature: A stylistic study of Helon Habila's Measuring time, European Journal of English Language and Literature Studies, 4(2)(2016), 13-21.

[9] Besancon. A., A century of horrors: Communism, Nazism and the uniqueness of the Shoah, Wilmington, DE: ISI Books, (2007) 
[10] Butcher. S. H, Poetics: Aristotle Trans. by S.H Butcher South Australia eBooks@ Adelaide, (2015)

[11] Fajrina. D., Character metaphors in George Orwell's Animal farm, Studies in English Language and Education, 3(1)(2016), 79-88, https://doi.org/10.24815/siele.v3i1.3391

[12] Gallese. V., The two sides of mimesis: Girard's mimetic theory, embodied simulation and social identification, Journal of Conscious Studies, 16(4)(2009), 1-24.

[13] Gerard. R., Violence and the sacred, Trans. by Patrick Gregory. Baltimore John Hopkins University Press, (1977)

[14] Habila. H, Measuring time, London: The Penguin Group.(e-version), (2007)

[15] Hill, J.L M and Lewis M.(2000) Classroom strategies, activities and exercises, In. Lewis M. (Ed) Teaching collocation, Hove: Language Publications.

[16] htpps://www.google.com.gh/amp/s/www.vanguardngr.com/2013/03/declining-family-affinitydecadence-in-society/amp/\#ampshare 14/11/2017

[17] Iherue. S.O, Causes and effects of moral decadence in Igboland: Socio-political, economic and religious perspective, (2011) (Unpublished Research) accessed from www.unn.edu.ng<files>images

[18] Leitao. A, Corruption and the environment, Journal of Socialomics, 5(3)(2016), 1-5,

[19] Macheka. T. M, An evaluation of post-colonial African leadership: A study of Ayi Kwei Armah's The beautyful ones are not yet born, and Chinua Achebe's A man of the people, International Journal of English and Literature, 5(1)(2012), 14-18, https://doi.org/10.5897/ijel11.087

[20] Marlowe. C., Doctor Faustus, Essex: Longman Group Limited, (1984)

[21] Melgar. N., Rossi. M. \& Smith. T. W., The perception of corruption, International Journal of Public Opinion Research, 22(1)(2010), 120-131, https://doi.org/10.1093/ijpor/edp058

[22] Napier. G.R, Origin stories and bleeding Kansas, Kansas history, A Journal of the Central Plains 34 (2011), 28-39

[23] Nina et al., Key terms in stylistics, London: Continuum International Publishing Group, (2010)

[24] Ogundipe. L. M., Re-creating ourselves: African women and critical transformations, Trenton: Africa World Press, (1994)

[25] Ovbiagele. H., Declining family affinity and decadence in the society, Vanguard News, (2013)

[26] Walker. A, In search of our mother's gardens, San Diego: Harcourt Brace Jovanovich, (1983), https://doi.org/10.2307/j.ctt5hjqnj.53

[27] Wiesel. E, Perspective without conscience, The New England Journal of Medicine, 352(15)(2005), 1511 to 1513 , https://doi.org/10.1056/nejmp058069 